\title{
Árvores de boa semente: silvicultura, preservação da natureza e agricultura na Primeira República
}

\author{
Trees of good seed: forestry, nature conservation and agriculture in \\ the First Republic
}

\author{
Roberta Barros Meira* \\ Mariluci Neis Carelli*
}

\section{RESUMO}

Este artigo é uma análise do pensamento em prol da silvicultura e da preservação das florestas brasileiras e do seu papel na organização e feitura do Serviço Florestal no Brasil durante a Primeira República. Foram analisados também a forte vinculação dessas ideias com os setores agrícolas. Nesse sentido, é um estudo sobre a valorização da ciência no Brasil e sua inserção tanto na agricultura como na exploração das riquezas naturais, mas especificamente, as florestas. Aborda com esse intuito o pensamento de cientistas, agricultores e estadistas reproduzidos em uma documentação que envolve o Ministério da Agricultura, revistas científicas e agrícolas, folhetos das secretárias da agricultura, dentre outros. Enfim, privilegia-se uma perspectiva teórica fundada na História ambiental, sintonizando o trabalho com questões econômicas.

Palavras-chave: Patrimônio natural. Agricultura. Silvicultura.

10 presente artigo representa parte de uma pesquisa ainda inconclusa, financiada pela Capes.

* Possui graduação e licenciatura em Historia pela Universidade Federal Fluminense (2004), Mestrado em História econômica pela Universidade de São Paulo (2007), doutorado em História econômica pela Universidade de São Paulo e é docente na Universidade da Região de Joinville. Tem experiência na área de História do Brasil, com ênfase em Historia Ambiental e Agrária.

** - Doutorado em Engenharia de Produção pela Universidade Federal de Santa Catarina, Brasil (2004). ViceCoordenadora do Mestrado em Patrimônio Cultural da Universidade da Região de Joinville, Brasil. 


\section{ABSTRACT}

This article is an analysis of thought in favor of forestry and preservation of Brazilian forests and their role in the organization and making of the Forest Service in Brazil during the First Republic. It also analyzed the links between these ideas with the agricultural sector. It is a study on the value of science in Brazil and its role both in agriculture and in the exploitation of natural resources, but specifically forests. Approaches to this end the thought of scientists, farmers and statesmen played on a document involving the Ministry of Agriculture, scientific and agricultural magazines, brochures of agriculture secretaries, among others. Finally, emphasis is a theoretical perspective based on the Environmental History, tuning and the economic issues.

Keyword: Natural heritage. Agriculture. Forestry..

Árvores há, de boa semente, boa terra e bons ares, que se criaram, para encantar os olhos com a formosura de sua grandeza, e proteger as criaturas com o benefício do seu abrigo.

Rui Barbosa

\section{Introdução}

Os discursos no primeiro quartel do século XX sobre as questões ambientais são testemunhos significativos para a compreensão da valorização da silvicultura no Brasil. Nesse sentido, os jornais agrícolas, os relatórios do Ministério da Agricultura e toda sorte de folhetos produzidos pelas secretárias de agricultura dos estados possibilitam uma apreensão do processo de transformação na exploração das riquezas naturais durante a Primeira República. Aliada à valorização da ciência e às crises de preços cafeeiras, as florestas brasileiras passaram a ser motivo de um maior interesse. O que reunia, naquele momento, diferentes atores - como agricultores, técnicos, acadêmicos e estadistas - era a busca por implementar um projeto de modernização no meio rural. Em consequência disso, a valorização das ciências florestais e da agricultura científica se fizeram sob o signo tanto das chamadas crises da lavoura como da circulação de saberes técnico-científicos com a realidade brasileira desse tempo.

A visão desse conjunto de elementos diversos que são inerentes deste projeto modernizador foi pouco aprofundada pela historiografia referente ao pensamento econômico, ambiental e científico brasileiro. Mais ainda, a questão florestal seria pouco estudada dado um interesse maior frente aos casos mais conhecidos, como a produção agrícola voltada para a exportação. Nesse sentido, esse trabalho tem como objetivo pensar a silvicultura não como um campo de ação à margem dos projetos de modernização da Primeira República, mas sim na margem das correntes de pensamento que se desenrolavam. Ou melhor, a contribuição vista no cultivo de árvores seria significativa para o projeto de diversificação e modernização colocado em marcha nessa época. 
Embora, o sentido aqui fosse de complementaridade dos principais produtos explorados pelo Brasil, como o café, havia uma rearticulação de diversos setores da economia em prol da silvicultura. Como se procura demonstrar, a lucratividade e a salvaguarda de parte das florestas - que poderiam advir com uma exploração racional - apresentavam-se como um argumento importante.

\section{1-Um grande campo para a exploração racional das florestas}

A primeira exploração comercial dada ao Brasil por Portugal seria a exportação de uma madeira corante, já conhecida por Pau-Brasil pelos europeus ou Ibirapitanga pelos indígenas. Já no primeiro século de exploração, o corte alcançaria 12 milhões de árvores (DEAN, 1996, p. 59-82). Em verdade, o ramo de comércio de madeira teve um notável desenvolvimento no decorrer da História Econômica do Brasil. Mais ainda, mantêm números importantes até os dias atuais. Ora, nessa ordem de ideias, percebe-se que essa história de uma economia madeireira tem em muito ampliado os seus limites quando se considera questões políticas e ambientais. Seria impossível realizar este estudo sem reconhecer a sua forte imbricação com a agricultura e, consequentemente, o crescente desflorestamento do território. Mas, na complexidade de um espaço em que uma diversidade de elementos era discutida e pensada como alternativa para as chamadas crises da lavoura, a exploração racional das matas brasileiras seria um ponto a ser debatido. Nesse sentido, queremos frisar, também, que na medida em que se fortalecia a defesa de uma agricultura científica no Brasil, algumas vozes começaram a defender fortemente a silvicultura.

A constatação defendida por Raymond Williams (1983) - de que anteriormente ao conjunto de transformações ocorridos ao longo do século XIX, o termo agricultura referia-se a algo que crescia naturalmente - deve ser considerada quando se analisa os debates dessa época. Assim como se deve ter em conta que a segunda metade do século XIX traria consigo o fato de que os principais progressos técnicos, - não necessariamente os restritos a agricultura -, passaram a estar relacionados com o uso das ciências puras e da metodologia científica nos experimentos, em detrimento dos métodos empíricos (HOBSBAWN, 1986, p. 161). Em suma, e na sua generalidade, percebe-se nos trabalhos voltados para o setor agrícola e madeireiro que a palavra ciência passou a significar quase uma entidade que agia como se operasse milagres. A ideia de uma agricultura e de um extrativismo que se desenvolviam sem os novos avanços técnicos era veemente qualificadas como práticas atrasadas e rotineiras. Assim, nada mais natural que muitos desses homens 
acreditassem que as bases sobre o que se sustentou o crescimento da Europa foram as inovações técnicas calcadas na "ciência moderna". 2

A questão de ser o setor extrativista e o agrícola fortemente imbricados fortaleceu as ideias de uma exploração racional dos recursos naturais. Fato é que não havia uma unanimidade em relação aos modos de exploração das florestas. A soma de trabalhos tanto de agricultores, técnicos e estadistas aponta a polemica sobre a questão. ${ }^{3}$ Por outro lado, esse ganho de importância entre atores diversos toma maior dimensão quando se considera a sua participação em atividades econômicas, políticas e acadêmicas fundamentais para a implementação dos projetos de modernização do país. Segundo De Luca (1999, p. 298), esses homens ao se colocarem como detentores de um saber específico explicitavam o seu papel de traçar e direcionar os rumos do país, - influenciando principalmente as políticas públicas priorizadas nesse momento. Exemplo disso era o próprio quadro de atores que orbitavam em torno do Ministério da Agricultura, Indústria e Comércio (MENDONÇA, 1990). e o enquadramento nítido de questões que estavam em sintonia com projetos que abarcavam os setores agrícola, madeireiro e ambiental.

Como o setor agrícola era o principal gerador de divisas, tornava-se coerente a manutenção de uma doutrina de glorificação das vantagens naturais do Brasil. No entanto, somava-se aqui à preocupação em melhor explorar essas riquezas naturais. Mais ainda, é preciso que se note o movimento de expansão de uma atividade até então somente exploratória para a defesa do cultivo de árvores. Embora, não fosse menos certo, que essas ideias não livrassem as florestas brasileiras de sofrer um constante processo de destruição. Por outro lado, é bastante esclarecedor o fato de que a perda acelerada das florestas em algumas regiões gerasse contrapartidas de proteção desde o período colonial. Como lembra Pádua (1987, p. 19) ao tratar da sociedade brasileira, "o ato fundador do Brasil [...] foi um projeto de exploração predatória da natureza". Mas, como bem observa o referido autor, esse quadro revela ao mesmo tempo uma visão crítica sobre os resultados observados nessas primeiras intervenções na natureza. Um exemplo seriam algumas medidas de proteção às matas como as adotadas no final do século XVIII, em função dos interesses da construção naval da Marinha Portuguesa.

Mas, merecem reparos, hoje, a pouca atenção dada pela historiografia aos discursos que tratavam das questões ambientais ou a percepção por muitos pesquisadores de serem estas intervenções anômalas. Não há como não reconhecer que alguns dos homens responsáveis pela legislação voltada à proteção da natureza do Primeiro Governo Vargas já propagavam suas ideias em prol da defesa da natureza no período anterior à 1930. É digno de nota, por exemplo, a atuação

2 Como coloca Amélia Hamburger et al. (1996, p. 16), a ciência moderna era usualmente identificada com a Europa Ademais, torna-se mais fácil entender este contexto se modificarmos o conceito comum de ciência e conceituamos a ciência como a prática de produção de conhecimento e aplicação de resultados que se estabelece.

3 Considera-se aqui que os atores que predominaram no projeto de modernização do Brasil podem ser classificados principalmente em três grupos: os grandes produtores agrícolas e as sociedades agrícolas, como a Sociedade Nacional da Agricultura; os técnicos, ou melhor, os engenheiros, agrônomos, botânicos, dentre outros e os estadistas. É comum perceber as ligações familiares ou a atuação de alguns desses atores em todas essas três frentes de atuação. Embora nem sempre esses homens possam ser vistos como um grupo uniforme e com os mesmos objetivos, se observa uma tendência muito grande à elaboração de projetos comuns. 
de Alberto José Sampaio ${ }^{4}$ desde esses anos. Não se poderia também esquecer a atuação do Ministério da Agricultura, Indústria e Comércio, da Sociedade Nacional da Agricultura, das secretárias de agricultura, do Museu Nacional, etc. As riquezas naturais, mas, especificamente, as florestas, começaram a ter o seu valor comercial sobressaído. Portanto, da releitura comercial e cultural da relação entre natureza, silvicultura e agricultura concretizavam-se novos olhares sobre a forma como se dava até então a exploração das riquezas naturais no Brasil.

Há nitidamente a existência de duas vias que levaram as questões florestais a serem postas na ordem do dia: uma seria que o maior interesse pelas florestas se deu à medida que 0 desmatamento avançava gerando várias consequências adversas. A outra, que nos parece curial seria o fato do comércio de madeira ganhar uma visibilidade maior na pauta de exportações brasileiras. Como esclarece Figueirôa (2008, p. 771), uma parte expressiva desses atores considerava que as riquezas naturais só eram importantes na medida em que eram apropriadas, ou seja, "justamente reconceituadas pelo próprio processo que delas se utiliza e as transforma". Essas duas vias são importantes porque nos revelam a visão de interdependência entre preservação da natureza, comércio de madeiras e agricultura. Ora, não se nega aqui que coadunavam pontos de vista diferentes. Embora pelo que se depreende dos documentos, essas diferenças não significaram a impossibilidade do desenvolvimento de projetos conjuntos de acadêmicos, estadistas, técnicos e agricultores.

A circulação de ideias europeias desempenhou uma atuação importante desse novo olhar para as florestas brasileiras à época. Na Europa, essa dicotomia em relação à natureza podia ser percebida desde o final do século XVIII, já se encontrando bem difundida no século XIX. Como escreve Keith Thomas (1996), passou a sofrer questionamento a imposição do domínio do homem sobre a natureza, gerando uma cisão na consciência moderna entre as necessidades materiais da sociedade e a importância de proteção, conservação e equilíbrio entre o homem e a natureza.

Por outro lado, como pondera Simon Schama (1996), pode-se identificar igualmente o surgimento de uma onda de racionalismo ou de administração florestal. Percebe-se uma maior importância dada às questões como a derrubada das árvores antes de sua maturidade, o acerto do desbaste drástico, a época do replantio, a necessidade de restringir-se ou até proibir-se a queima da madeira. Foi em parte por força dessa aliança entre os defensores da preservação das florestas e o fato da cultura de árvores transformar-se em um ativo econômico que a silvicultura se constituiu numa verdadeira ciência da economia florestal. O Brasil não seria um caso isolado no novo status concedido às florestas e a ciência. Desse modo, não seria de se estranhar que as ciências aplicadas à agricultura e a melhor utilização das riquezas naturais acabassem por se caracterizar como campos específicos do saber, como a agronomia e a silvicultura.

4 Alberto José Sampaio nasceu em Campos dos Goytacazes, no estado do Rio de Janeiro, em 1881. Em 1905, via concurso público, assumiu a função de Assistente de Botânica no Museu Nacional, instituição em que, a partir de 1912, passou a trabalhar como professor e chefe da Seção de Botânica. Tornou- se um dos mais importantes botânicos do Brasil. (FRANCO; DRUMMOND, 2009). 
Mas, esse projeto de transformação que pautaria essa nova relação dos brasileiros com suas florestas é um pouco mais complexo do que o simples transladar dos modelos estrangeiros. Temos uma importante fração da sociedade brasileira que de modo fragmentário iria incluir as questões florestais na sua pauta. Esse pensamento, não desprezível entre os agricultores é encontrado tanto nas revistas agrícolas, nos relatórios do MAIC, nos anais de congressos agrícolas, dentre outros documentos do período. Efetivamente, $\mathrm{o}$ aumento das áreas produtivas agrícolas e 0 desflorestamento intensivo sofrido no país sintonizavam-se com a perda de fertilidade dos solos e as mudanças climáticas, principalmente a diminuição das chuvas.

Mesmo de modo não sistematizado havia referências explícitas a necessidade de racionalização da lavoura como forma de evitar problemas gerados pelo desmatamento. Sabe-se que foi comum no Brasil instalar novas fazendas em terras cobertas por matas virgens, não só para aproveitar a fertilidade do solo, mas também assegurar as madeiras de construção e combustível. Mas, a abundância de árvores nem sempre era sinônimo de terras férteis ad eternum e não poucas vezes os proprietários se chocaram com essa realidade. Como bem foi destacado no caso da perda da fertilidade do solo na região do Vale do Paraíba Fluminense por Stanley Stein (1981). Mas, cabenos colocar que mesmo as mudanças climáticas, como a diminuição das chuvas, também fizeram parte de alguns relatos, gerando uma certa dose de preocupação. ${ }^{5}$

Caberia dar atenção a dois artigos publicados na Revista Florestal Brasileira, em novembro de 1902. No trecho inicial do primeiro escrito, o agrônomo Octavio da Silveira Mello, afirmava que atores distintos como "agrônomos, amantes da natureza e até os coronéis da agricultura já emitiram os seus sábios conselhos em prol da defesa das nossas matas". O deputado Nelson Catunda vai adiante ao chamar a atenção em um artigo neste mesmo número da Revista sobre o reflorestamento no Nordeste brasileiro e os problemas da seca. Segundo ele, no sudeste do país observava-se igualmente idêntico fenômeno, embora em menores proporções. Seria interessante a utilização do trabalho de Euclides da Cunha para dar a devida força ao seu pensamento. Assim, "o autor dos sertões, condenando as devastações das matas em São Paulo, impressionava-se já com o gradativo abaixamento de nível de certos rios paulistanos e dos de outras zonas cafeeiras, por destruição das florestas nativas" (REVISTA FLORESTAL DO BRASIL, 1902).

Os homens da primeira metade do século XX já tinham conhecimento que os princípios provenientes da chamada "agricultura científica" e da silvicultura adotados por muitos países concorrentes, poderiam minimizar os problemas causados pelo desmatamento das áreas agrícolas. Sendo um exemplo ilustrativo, o caso dos produtores de açúcar brasileiro. Embora, a lenha continuasse a ser utilizada como o principal combustível tanto para usinas como para pequenos engenhos, as questões ambientais já figuravam em algumas falas do período, seja pelo custo com combustível ou mesmo pelas mudanças climáticas. Este problema se acentuou com a utilização cada vez mais frequente de máquinas tocadas a vapor na segunda metade do século XIX. O ponto

5 A meteorologia iria se firmar no Brasil a partir do final do Império. De acordo com as informações desse cientista, em 1917 o Brasil possuía 222 estações meteorológicas espalhadas em seu território - ou seja, uma estação para cada 38.224 Km. Ministério da Agricultura (BARBOZA, 2006, p. 1-6). 
crítico representado pelos altos gastos com combustíveis somado aos problemas do solo e do clima aumentaram os clamores por fontes alternativas que reduzissem o consumo de lenha.

Chama a atenção a defesa dos fornos de queimar bagaço verde. Parte dessa discussão estava relacionada diretamente a escassez da lenha e do preço elevado do carvão de pedra. Este problema se tornava cada vez mais angustiante com o desaparecimento das matas no entorno destas fábricas, ou seja, a utilização do bagaço era cada vez de maior necessidade. A adoção dessa tecnologia seria enfatizada em diversos periódicos agrícolas. A revista $A$ lavoura em um dos seus artigos demonstrava aguda percepção ao citar a bem-sucedida adoção dos fornos de queimar bagaço verde no então maior produtor mundial de açúcar. (MONZOTE, 2002, p. 186-213). Impressiona particularmente ter frisado que nas fábricas cubanas perfeitamente montadas, 0 produto do bagaço era suficiente para suprir todo o vapor sem o consumo de lenha. (REVISTA A LAVOURA, 1920).

As secas tornaram-se igualmente uma preocupação ao longo dos anos. Concentrado em apontar efetivas melhorias de mecanização para os recém comprados engenhos centrais da companhia francesa Société de Sucréries Bresiliennes, o engenheiro francês Picard ${ }^{6}$ defendia como uma das mais urgentes medidas a substituição da lenha pelo bagaço de cana como combustível para as fornalhas. A consequência do sistema adotado até então era o desmatamento ainda maior das terras das usinas e a compra de lenha de terceiros. Já no ano de 1903, iria expressar a sua preocupação com as mudanças nos regimes pluviais:

\footnotetext{
Pode-se observar neste sentido que os terrenos mais secos são precisamente aqueles cultivados há mais tempo e nos quais as florestas, que a alguns anos cobriam quase todo o Brasil, tornaram-se cada vez mais espaçadas. Este é o caso de Villa Raffard, onde não se vê mais do que alguns pequenos bosques aqui e ali. As culturas ali estão mais ressequidas do que em outros lugares, e neste ano, a seca foi suficiente intensa para causar uma grande queda das colheitas. (PICARD, 1996, p. 17).
}

É manifesto que as ressalvas em relação à destruição das florestas foram feitas no sentido de não prejudicar a agricultura. O aumento das áreas de terras cansadas e estéreis, as secas e a falta de combustível passaram a constar na pauta do MAIC, das secretarias e das associações agrícolas. O objetivo maior era defender um sistema mais racional de produção, no qual a natureza fosse melhor aproveitada. Apoia-se aqui na fala de Leff (2009, p. 99-114), quando ele entende que as práticas agrícolas são potencializadas por "tecido de valores, de formação ideológicas, de sistemas de significação, de práticas produtivas e de estilos de vida, num contexto geográfico e num dado

6 J. Picard esteve no Brasil em uma missão de inspeção feita entre 1 de março a 15 de julho de 1903. 
momento histórico". Assim é que a recriminação ao desmatamento descontrolado só passou a ser uma realidade a partir do momento em que houve uma necessidade sentida pelos próprios agricultores. Cabe não esquecer, entretanto, que as dificuldades de transição de um modelo de produção para outro são visíveis para estes homens. Aliás, seus discursos constituíram em parte o imaginário negativo que se criou em torno do sistema extensivo de produção, mesmo que ele não tenha sido superado neste momento.

Um dos casos mais ilustrativos dessa inter-relação foi a atuação da Sociedade Nacional de Agricultura. Aliás, no seu primeiro regulamento, a SNA apresentava-se como uma "agremiação de lavradores e de amigos da lavoura", que ocupar-se-ia de todos os assuntos que pudessem trazer o "progresso agrícola" ao Brasil. Mas, atenção particular deve ser dada ao entendimento do que comporia a sua alçada, isto é, "tudo que possa referir-se às águas e florestas, aos assuntos agrários, à cultura do solo, a criação e às indústrias rurais" (Revista a Lavoura, 1897). Tem-se a nítida impressão que houve uma sistematização da importância econômica das florestas tanto quando se fala da sua percepção como mais um elemento econômico a ser explorado como da interdependência da sua manutenção com as vantagens naturais da agricultura brasileira.

Em 1901, a SNA organizou o Primeiro Congresso Nacional de Agricultura. Esse primeiro Congresso se sobressaiu, uma vez que nele foram formulados os principais pontos debatidos em torno da agricultura durante toda a Primeira República. De certo modo, a preservação da natureza foi chamada à baila nesses primeiros anos com a função de evitar erosões no solo e proteger os mananciais aquíferos. Dessa forma, havia uma justificativa perante os olhos destes congressistas, mesmo que a natureza não fosse colocada em primeiro plano. Alguns argumentos em favor da agricultura intensiva já acenavam como uma saída possível para o desmatamento. Nesse sentido, os congressistas advogaram em defesa de "medidas severas contra a devastação das matas, mormente daquelas situadas nos cumes das montanhas, serras, outeiros, ao lado de mananciais e a organização da polícia sanitária agrária" (SOCIEDADE NACIONAL DE AGRICULTURA, 1907, p. 81).

Vê-se, assim, que esses discursos teóricos e ideológicos de glorificação da ciência em detrimento das práticas tradicionais do campo refletiram em parte a necessidade de transformação do comportamento dos principais atores frente à exploração das riquezas naturais do Brasil. Embora, cabe colocar, que as questões ambientais não se constituíram em uma preocupação principal para muitos desses homens ligados à agricultura. Seria manifesto, por outro lado, a preocupação em não prejudicar a agricultura. Assim, a proteção à natureza deveria existir para auxiliar a recuperação dos tempos áureos da exportação agrícola brasileira. Dessa feita, a destruição das florestas não estaria ligada à ideia de progresso, mas sim as técnicas rotineiras de cultivo que ainda vigoravam. Aliás, a enxada e a coivara seriam alçadas à símbolos do atraso do país frente a glorificação da figura do arado, da irrigação, da adubação, dentre outras inovações agrícolas do período. 
Assim é que um trabalho nesse sentido teria sido estimulado pelos homens ligados à agricultura, embora uma justa apreciação do problema reconheça que foram esforços de vários setores, com graus variados de empenho e em várias esferas de poder, que resultaram na criação do Serviço Florestal do Brasil ainda na Primeira República. Como diria um artigo do Boletim do Ministério da Agricultura, Comércio e Obras Públicas, "o grave assunto infelizmente, já preocupa os poderes públicos de nosso país e não só o Ministério da Agricultura, como vários governos estaduais, tem providenciado para a organização do Serviço Florestal do Brasil”. (BRASIL, 1925b, p. 80).

\section{2-A organização do Serviço Florestal e as madeiras que distinguem o Brasil.}

A maior defesa da silvicultura que marcaria a Primeira República teria como precursor os trabalhos desenvolvidos principalmente pelo Jardim Botânico e o Imperial Instituto Fluminense de Agricultura. Um bom exemplo da importância dada às pesquisas com plantas indígenas e exóticas e seu potencial uso para a agricultura pode ser percebida pela presença do Imperador D. Pedro II nas sessões do Instituto. Além dos valores expressivos destinados ao financiamento das pesquisas do IIFA nesses anos. ${ }^{7}$ Havia assim uma tradição em fazer caminhar conjuntamente os interesses agrícolas com os estudos das riquezas naturais do país. Certamente, teve precedência que remonta ao final do Império a ligação entre a silvicultura e os ideais de diversificação econômica no campo. Releva notar, no entanto, que houve uma necessidade maior de aumentar a gama de produtos agrícolas voltados para a exportação nos anos seguintes, principalmente com as crises nos preços do café (MENDONÇA, 1990).

Por outro lado, após o final do Império, o Ministério da Agricultura seria extinto, sendo recriado apenas em $1909 .{ }^{8}$ Assim, coube as secretárias de agricultura - organizadas pelos estados após a Constituição Republicana de $1891^{9}$ - tentar racionalizar o processo produtivo. Como se pode facilmente imaginar as secretárias de agricultura se constituíram nos grandes pilares das políticas idealizadas para a renovação da agricultura nestes anos. Eram objeto de suas preocupações a organização de estações agronômicas, fazendas-modelo, campos de demonstração, a distribuição de plantas e sementes, a colonização e imigração, o serviço de reflorestamento, de inspeção e defesa agrícola, de propaganda de tudo que pudesse interessar à agricultura, a legislação rural, dentre outros. Ora, essas secretárias tratavam justamente de colocar na prática a ideologia dos

\footnotetext{
7 Em 1860, ano de fundação do Ministério da Agricultura, Comércio e Obras públicas, o Imperial Instituto Fluminense de Agricultura recebeu o valor de 24:000\$000 réis. (BRASIL, 1861, p. 5)

8 Ver: Bhering e Maio (2011, p. 689-709) e Sociedade Nacional da Agricultura (1906).

9 A constituição de 1891 concedia maior autonomia aos estados brasileiros para administrar os seus territórios e orçamentos.
} 
defensores de uma agricultura cientifica que marcaram esta época. Aliás, a defesa da atuação dessas secretárias seria feita por Edmundo Navarro de Andrade ${ }^{10}$.

A trajetória de Navarro de Andrade como um dos principais nomes da silvicultura brasileira teria começado com os estudos em Coimbra, onde estudou na Escola Nacional de Agricultura. Logo após o seu retorno, ele iniciou carreira no programa florestal posto em marcha pela Companhia Paulista de Estradas de Ferro, - com a criação do Horto Florestal de Jundiaí pela Companhia. Começando, assim, seus estudos com essências florestais já em 1904, trabalhando tanto com árvores nativas como exóticas - como seria o caso do eucalipto (MARTINI, 2004). A figura 1, que faz parte do livro publicado por Navarro, "A utilidade das florestas" é um bom exemplo da valorização dada ao cultivo do eucalipto já nesse momento. Assim, como as experiências com variedades distintas e a sua adaptação no Brasil. Demais, não pode deixar de ser lembrado que ele fez parte de um grupo de técnicos e cientistas nacionais e estrangeiros contratados pelo Governo para obter melhor aproveitamento dos recursos naturais. ${ }^{11}$ Como todos os que seguiram este percurso nesse período, as suas ideias inclinavam-se para a defesa de uma modernização racional. Assim parte da diversificação da produção tão almejada por esse projeto seria feita através da silvicultura, podendo ser implantada em todo o país, tanto por grandes como por pequenos produtores.

\section{Figura 1}

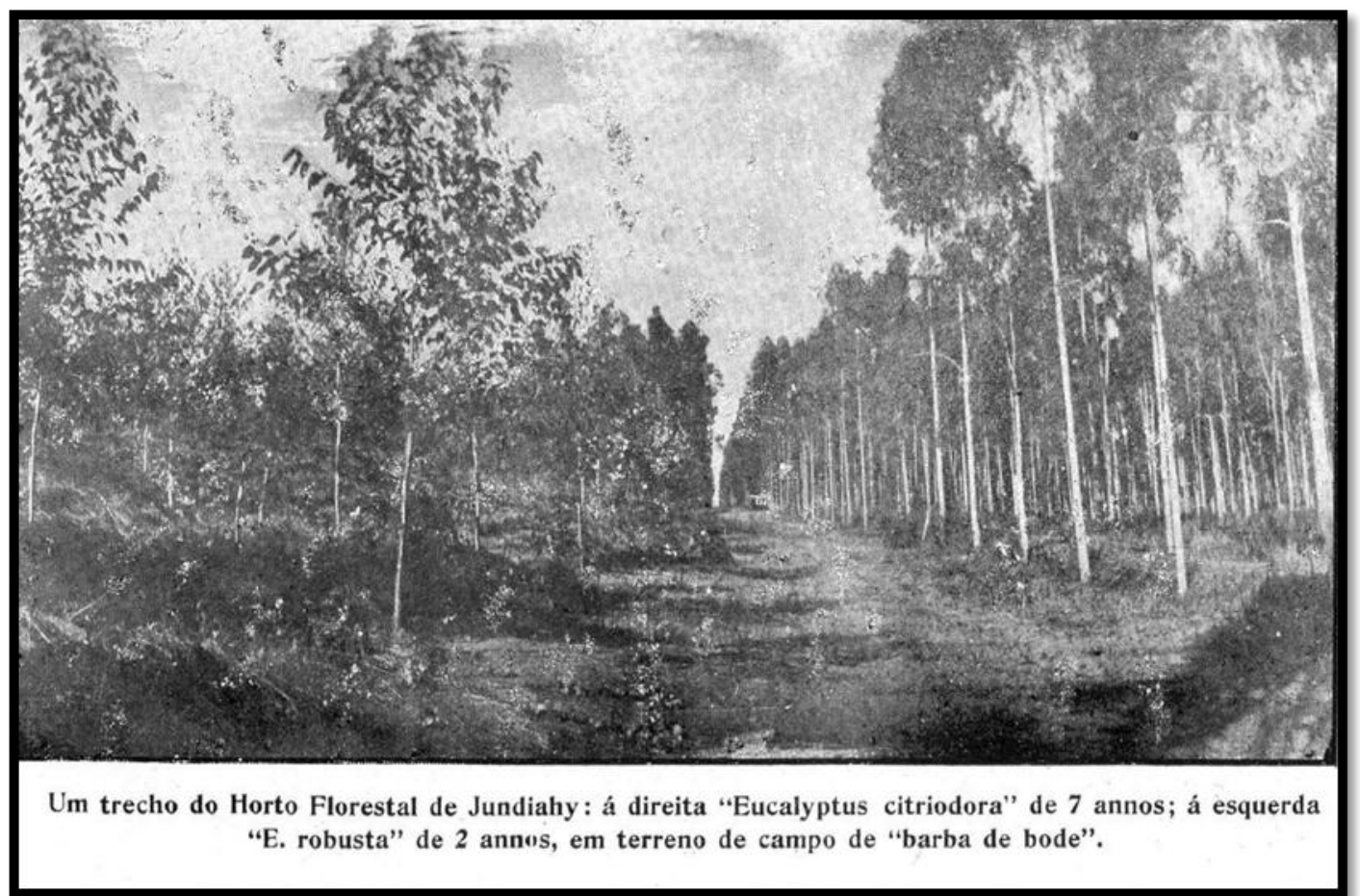

Fonte: Andrade (1912, p. 95).

10 Edmundo Navarro de Andrade era diplomado pela Escola Nacional de Agricultura de Coimbra e chefe do Serviço Florestal de São Paulo.

11 Além de Edmundo Navarro de Andrade, o Governo contrataria Orville Derby; Franz W. Dafert; Hermann von Ihering, Alberto Loefgren. (FRANCO; DRUMMOND, 2009). 
Segundo Navarro de Andrade, a Secretária de Agricultura do Governo do Estado de São Paulo teve o importante papel de distribuir mudas, divulgar instruções e estabelecer culturas florestais em diferentes pontos do seu território (ANDRADE, 1912, p. 96). De fato, observa-se que as secretárias estaduais tiveram um papel fundamental na diversificação da produção nos estados cafeeiros. Ao estudar esses anos não há como negar a propaganda realizada por técnicos e pelo próprio Estado na tentativa de solucionar os problemas da cafeicultura através do incentivo a policultura. Isto não quer dizer, em absoluto, que medidas similares não fossem adotadas anteriormente, mesmo que não fossem de forma tão evidente. O próprio MACOP desde a sua criação buscou além de melhorar as culturas existentes, estimular a produção de outras. Nesse sentido, fazia a distribuição de mudas de variedades estrangeiras de café e de açúcar, mas também inovaria ao tentar aclimatar no Brasil os eucaliptos da Austrália e trazer sementes de trigo da França para as províncias do Sul, oliveiras para Santa Catarina e Minas Gerais, videiras da llha da Madeira para São Paulo, sementes de Alfafa da Argentina, dentre outras culturas (BRASIL, 1875).

Como é sabido, as crises de superprodução cafeeira atenderam em parte à responsabilidade por uma visão condenatória da monocultura. Dessa feita, a dedicação exclusiva a um só produto passou a ser vista como um dos reforços para o atraso. Acentuando-se cada vez mais com a continuidade da crise dos preços dos principais produtos de exportação do Brasil. No limite, tal atitude resultou num total encorajamento a mudança nos princípios que caracterizavam os espaços produtivos do país, marcados até então por uma certa especialização. A policultura seria entendida nestes anos como uma prática estabilizadora que minimizaria em parte as frequentes oscilações dos preços desses produtos no mercado externo. ${ }^{12}$ Este pensamento tão representativo da época se refletia sempre sobre o produto mais marcante da realidade de cada região ou mesmo de um país, retratando principalmente as crises de superprodução mundiais.

Nesse quadro de insegurança gerada pela dependência da balança comercial frente o café, a silvicultura começou a aparecer como um dos novos gêneros a serem incentivados. Em uma cartográfica agrícola produzida pela secretária de agricultura de Minas Gerais em 1929, a extração de madeiras figurava como uma solução, juntamente com a pecuária, o algodão, o arroz, a cana de açúcar, dentre outros produtos agrícolas. Curiosamente, em torno do mapa foram traçadas pequenas imagens representativas das principais atividades agrícolas e extrativas, como no caso da figura 2. O fato de a extração de madeiras ser na ordem de $208.000 \mathrm{~m}^{3}$ pode ser considerada uma explicação para este destaque. Sendo que em matas o Estado contava com $143.490 \mathrm{~km}^{2}$ de uma superfície de $602.239 \mathrm{~km}^{2}$ (MINAS GERAIS, 1929). Ademais, a própria ferrovia anteriormente incentivadora do café, poderia ser utilizada como estrutura para o desenvolvimento desses novos produtos. Nesse caso específico, enfatizava-se que a comunicação com essa serra se fazia com

12 Cliff Welch destaca que policultura é uma expressão contemporânea de uma prática antiga, a policultura entrou na linguagem no século XX. A palavra, como o seu significado, é uma resposta oposta, um antônimo a uma outra palavra nova: monocultura. Enquanto a monocultura se refere à cultivação de um produto só, quando seria possível cultivar muitos, a policultura significa a cultivação de uma variedade de culturas quando seria possível plantar um só. Então a monocultura é homogeneidade, policultura, heterogeneidade; monocultura é tradição, policultura, modernidade. (WELCH, 2005, p. 355-357). 


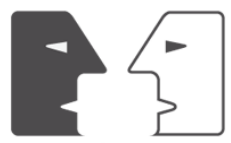

ANTÍTESES

relativa facilidade partindo-se da Estação de Caparaó, sendo escoados diversas espécies de Ipê, Peroba, Cabiúna, Cedro, Garapa, Jequitibá, Ubatã, Mirandiba, dentre outras madeiras. (BRASIL, 1926, p. 15-21).

Figura 2

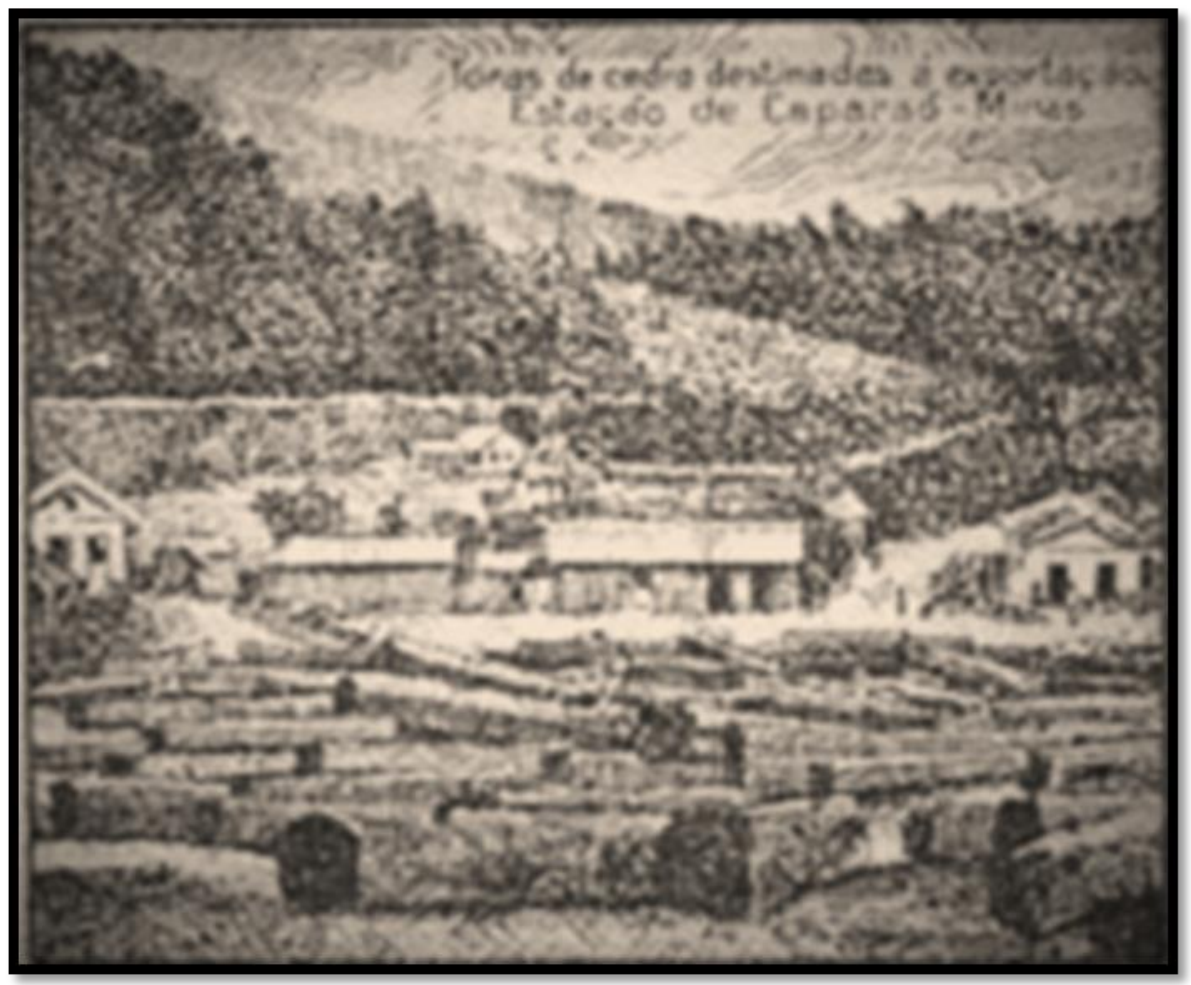

Fonte: Minas Gerais (1929).

O que importa deixar aqui claro seria a originalidade da relação entre a agricultura e a silvicultura. Mesmo possuindo uma imbricação em tempos anteriores, essas duas atividades desenvolveram uma maior integração nessas primeiras décadas do século $X X$, consolidando mais $e$ mais como uma alternativa para terras cansadas ou um novo ativo para o campo. Impossível não reconhecer aqui um maior interesse em relação as florestas. Mas, deve merecer particular atenção saber como esses processos estavam se consolidando, que atores seriam responsáveis pela sua idealização e implementação, se chegaram a ter poder para tal, para o que o queriam e para que servia, ou seja, estaria voltado para atender em parte o mercado interno ou estaria em grande parte idealizado como uma possibilidade de aumento da balança comercial brasileira, ou ambos. Essa necessidade de diversificação agrícola entrelaçada com a questão florestal gerou novas linhas de interpretação que não podem deixar de ser levado em conta quando se pensa uma História Ambiental, que se vincula profundamente com a História Econômica. 
É bom lembrar que as ideias de ciência e progresso material ${ }^{13}$ aparecem como o ideal de uma geração de homens cujo papel foi fundamental em implementar as bases de uma política voltada para as florestas nesse período. Em um folheto em que faz uma forte crítica ao código florestal, Navarro de Andrade chamava a atenção para o fato de que nos novos países, as melhores terras sendo as que estão revestidas de matas, havia uma inevitabilidade na sua derrubada para a agricultura. O exemplo citado seria o próprio caso do café em São Paulo, que "não seria o primeiro estado da União, o mais rico e adiantado, se não tivesse substituído as densas florestas das suas terras roxas pelo café" (ANDRADE, 1912, p. 96). Isso não significava que ele não defendesse a importância do reflorestamento. Mas, sim, que fosse feito, de um modo prático e racional. Ou seja, valendo-se das terras mais pobres, impróprias para outras culturas, uma vez que esse cultivo de árvores demandava terras menos exigentes.

Como já havia sido notado por Worster (2004, p. 120), "Quizás tal escrutinio haga que algunos héroes del pasado luzcan un poco menos heroicos, pero a fin de cuentas el hecho de situar sus vidas y sus ideas dentro de la historia nos proporciona una perspectiva mucho mejor sobre los problemas de hoy". Naturalmente, não é possível enquadrar esses homens na visão romântica que vigora atualmente sobre os ecologistas. (WHITE, 2013, p. 472-491). Ora, como também por todas as razões já expostas não é possível considerar a sua contribuição para a proteção das florestas brasileiras como irrelevante pelas questões comerciais se constituírem em preocupação principal nos seus trabalhos.

$\mathrm{Na}$ verdade, como Navarro de Andrade faz referências, essas ideias seguiam em parte um modelo que já criara raízes em outros países. Como outros homens desse período, ele percebeu que a ampliação do consumo de madeira mundial determinava uma demanda pela proteção das florestas e uma alternativa econômica criada pelo reflorestamento das terras cansadas. É ilustrativo que o agrônomo tenha escolhido usar como referência uma citação do trabalho do Auguste Mathieu $^{14}$, que dizia:“Dans um pays bien ordenné, les forêts doivent céder à l'agriculture les terres fertiles et n'occuper que celles de la moindre qualité" (ANDRADE, 1912, p. 98). É oportuno notar, nesse caso, a formação de uma rede de circulação de ideias que mais do que uma agricultura científica voltava-se também para a silvicultura. Segundo o autor era preciso:

[...] matas uniformes, homogêneas, de uma só, ou de reduzido número de espécies, cuja exploração possa ser, mais tarde, feita segundo as regras da silvicultura e cujos lucros correspondam aos que se podem e devem obter da cultura florestal, sem o processo bárbaro de derrubar muitas árvores para

13 Como aclara Sevcenko (2003, p. 67) sobressai-se, nesse momento uma "corrente de pensamento que nutrira todo o processo de remodelação das sociedades europeias no século XIX, e que agora, chegado ao seu fim, via-se revigorada pela aura da ciência e do progresso material, assomando como o próprio amálgama promissor da máxima racionalidade, fartura, paz e felicidade possíveis".

14 Auguste Mathieu era professor da École Nationale du Génie Rural, des Eaux et des Forêts de 1838-80, que tinha uma longa tradição de ensino florestal. (GUYOT, 1898). 
aproveitar alguns metros cúbicos de uma determinada essência e sem a necessidade de vender, a um preço irrisório, como lenha, madeira de inestimável valor (ANDRADE, 1912, p. 98).

Á vista dessas ideias, a já conhecida leitura particular dos usos de uma natureza percebida frequentemente como inesgotável sofreu uma certa reformulação no período, dando espaço para o cultivo de florestas. A defesa de um modelo de desenvolvimento pautado no avanço predominantemente econômico e uma exploração mais racional da natureza mereceu especial cuidado por parte de técnicos estrangeiros que se encontravam no Brasil nesse período. Exemplo disso seriam os trabalhos como os de Hermann von Ihering ${ }^{15}$ que analisaram em que medida a silvicultura poderia minimizar os problemas ambientais. Segundo ele, eram três os fatores que compunham a questão da conservação das matas no Brasil, ou seja, o fornecimento de lenha, a extração de madeira de lei e a defesa das matas próximas aos mananciais dos rios e ribanceiras, que afetavam tanto o clima quanto o abastecimento de água. Ihering chegou a defender que se a experiência europeia fosse transladada para o Brasil, o Estado de São Paulo tiraria tanto lucro da silvicultura como naquele momento obtinha com o café e "o caipira elemento prejudicial às matas, com pouca disposição para prestar serviços regulares na lavoura do café, dedicar-se-á com gosto ao serviço florestal e ao transporte de seus produtos". (Revista do Museu Paulista, 1911, p. 497).

Novamente aqui, a circulação de ideias e a importância dada às experiências comerciais, políticas, tecnológicas e científicas de outros países ensejaram uma maior defesa da silvicultura. A Inglaterra, a Alemanha e a França seriam comumente citadas nesse momento pelo êxito do seu sistema de exploração racional das florestas. Em relação à Alemanha, Ihering apontava que uma população maior que a de todo o Estado de São Paulo devia seu sustento à cultura das matas e às indústrias relacionadas com a mesma (Revista do Museu Paulista, 1911, p. 494). Esse intercâmbio de informações possibilitaria a alguns dos homens desse período fazer um amplo painel da situação das florestas brasileiras comparativamente a de outros países. Em meios aos debates travados nesse momento, uma parte dos discursos defenderia que a criação de condições efetivas para tirar algum tipo de ganho das florestas, preferencialmente o econômico, seria fundamental para a preservação de parte da natureza brasileira.

Desde os primeiros anos da República, esses atores já haviam se articulado por uma maior atuação do Estado na conservação e exploração das florestas. É preciso, contudo, não esquecer a influência de medidas similares tomadas em outros países que lhes forneceu muitos dos seus fundamentos, como a Inglaterra (THOMAS, 1996). Assim como o fato de o crescimento da importância dos "homens da ciência"- químicos, agrônomos, botânicos, engenheiros e os chamados "agricultores progressistas" se nos afigura fundamental dado o crescimento concomitante das novas

15 Ihering foi um médico, professor e ornitólogo alemão, naturalizado brasileiro em 1885. Em 1892, foi um dos responsáveis pela fundação do Museu Paulista, do qual foi diretor por 25 anos. Foi também o criador do Jardim Botânico. 
diretrizes de exploração racional das florestas brasileiras e a crescente importância desses novos atores. Ou mais precisamente, eles se percebiam como intermediários entre a ciência, a agricultura e a exploração das riquezas naturais do país.

A mobilização em torno das questões florestais durante a Primeira República resultou na defesa da Criação do Serviço Florestal. O decreto legislativo n. 4421, promulgado no ano de 1921 , que criava o Serviço Florestal do Brasil, visava a restringir significativamente os males causados pelo desflorestamento, escorado em parte na minimização dos efeitos pela silvicultura. Mas, a preocupação em explorar o comércio de madeiras seria a base de sustentação desse projeto. Pode parecer paradoxal que essas aspirações nascessem juntas. Como destaca Franco e Drummond (2009, p. 68), o projeto de criação do Serviço Florestal contaria com importantes acadêmicos do período. Alberto José de Sampaio elaborou um programa que colocava sob responsabilidade do Serviço Florestal funções tais como: pesquisa, controle e implementação das florestas produtivas no Brasil. O principal ponto acenado em 1926 seria que o trabalho do recém-criado Serviço Florestal faria com que o Brasil ocupasse em breve o posto de um dos maiores países produtores de madeiras, conservando ao mesmo tempo o máximo possível de suas florestas (SAMPAIO, 1926). Assim, nesse momento, a silvicultura tornava-se um ponto crucial e não faltaram vozes que propunham a expansão do cultivo de árvores.

Por outro lado, o fato do programa elaborado por Sampaio ser apresentado no Congresso Internacional de Silvicultura de Roma aponta para uma expressiva circulação de ideias em inúmeros países. Considera-se importante, por exemplo, a influência norte-americana na criação do Serviço Florestal no Brasil e a sua incorporação ao Ministério da Agricultura. O projeto de criação do Ministério da Agricultura, Indústria e Comércio enfatizava o processo de transferência de experiências de ministérios da agricultura em outros países, sendo a sua menina dos olhos o ministério da agricultura americano (SOCIEDADE NACIONAL DE AGRICULTURA, 1906). O que chama mais atenção, no entanto, seria a criação de uma diretória dentro do Ministério da Agricultura norte-americano, denominada Serviço Florestal, em 1905. Assim como os seus principais objetivos: "administrar e proteger as florestas nacionais, além de estudar um grande número de problemas florestais gerais e distribuir informações referentes à silvicultura" (BRASIL, 1922, p. 16-17).

Essa aproximação de ideias e de políticas de proteção e exploração racional das florestas adotada em outros países fundamentou em parte os rumos seguidos no Brasil. Quando se analisa os nomes da comissão responsável pelo projeto do Serviço Florestal percebe-se igualmente a congregação de interesses de diversos setores. Fizeram-se presentes nomes como o da já citado Edmundo Navarro de Andrade, Domingos Sérgio de Carvalho ${ }^{16}$. Francisco de Assis Iglesias ${ }^{17}$, Arthur Torres Filho ${ }^{18}$, José Marianno Filho ${ }^{19}$, dentre outros. No mais, percebe-se ao mesmo tempo a

16 Engenheiro agrônomo, membro do corpo técnico do MAIC, lente do Museu Nacional, diretor da Seção de Antropologia e Etnologia, participou da diretoria da SNA, foi autor do primeiro projeto de regularização da profissão de engenheiro agrônomo, em 1933.

17 Agrônomo, foi diretor da Diretoria de Ensino Agrícola da Secretaria da Agricultura, Diretor da Inspetoria Agrícola do Ministério da Agricultura e futuro Diretor do Serviço Florestal do Brasil.

18 Diretor da Estação Experimental de Campos e do Serviço de Inspeção e Fomento Agrícola.

19 Diretor da Escola Nacional de Belas Artes. 
forte presença de estadistas, organizados pelo próprio Ministro da Agricultura, Miguel Calmon du Pin e Almeida ${ }^{20}$ (BRASIL, 1929, p. 317) Embora fosse ditada por interesses vários e grupos de homens com diferentes projetos, o Serviço Florestal nasceu de uma visão integrada de que se era preciso valer da ciência em todas as esferas de atuação. A racionalização dos usos dos recursos naturais, a silvicultura e a proteção das chamadas florestas protetoras integraram-se ao conjunto dos pilares das políticas florestais a partir deste momento.

Nesse sentido, a complexidade das relações entre o Estado, a agricultura e as florestas assumiram novas feições à medida em que se construía um projeto de silvicultura para o país. Demais, vale lembrar que a segunda metade do século XIX e a primeira do XX foram marcadas por mudanças radicais na forma como a agricultura e o extrativismo estavam estruturados. Tendência salutar e compreensível diante dos interesses dos grandes proprietários rurais e que de certo modo se delineia como uma resposta coordenada a partir de um nível mundial. Naquela época, o Brasil já não tinha condição de concorrer com outros países se não aplicasse os aperfeiçoamentos técnicos e se igualasse aos seus rivais. Esses novos saberes e técnicas fariam muitos dos homens do período repensarem a forma como se explorara a natureza até então, principalmente quando se tratava das florestas. Desse modo, a valorização da silvicultura emergiu de situações próprias dessa época, qual seja, o da propagação do sistema intensivo de culturas e do incremento da exportação de uma gama maior de produtos como forma de reafirmação da vocação agrícola do Brasil.

A magnitude das discussões do período levava a considerar não apenas o grau de atenção que seria concedida à preservação da natureza, mas, do mesmo modo, quanto o país podia se valer das exportações de madeiras para incrementar a sua balança comercial e atender uma demanda crescente no seu mercado interno. É preciso que se considere que se a atuação do Estado já era vista como uma condição indispensável à continuidade das florestas, o interesse em implementar políticas de incentivo à sua exploração seria muito mais evidente nesta época. Exemplo disso seria um volume financiado pelo Governo brasileiro de mais de mil páginas intitulado "Impressões do Brasil no século XX: sua história, seu povo, comércio, indústrias e recursos". 0 trabalho continha um relato minucioso da paisagem, dos variados climas, das principais culturas agrícolas e da atividade extrativista, da fauna e da flora, enfim, divulgava-se o país pelas suas riquezas naturais. Mas, o que mais interessa perceber seriam as descrições das madeiras e suas possibilidades de exploração:

O Brasil que possui, sobre a vastidão de sua área, principalmente na bacia amazônica e ao longo da costa oriental, imensas florestas atravessadas por caudalosos rios - entre os quais o Amazonas e seus afluentes constituem verdadeiros mares internos - é um dos países mais ricos de madeiras. $\mathrm{E}$ tanto

20 Miguel Calmon Du Pin e Almeida pertencia a uma proeminente família baiana, cursou engenharia na Escola Politécnica do Rio de Janeiro. Publicou diversos trabalhos sobre a indústria açucareira e assumiu diversos cargos públicos, entre os quais o de Ministro da Agricultura, Indústria e Comércio. Ademais, foi presidente da Sociedade Nacional da Agricultura entre 1921-23. 
isto é real, que cada hectare em floresta pode ter o valor de 4:000\$ em madeiras. As árvores colossais, algumas das quais medem até 10 metros de circunferência, como geralmente acontece com as espécies denominadas jequitibás, podem dar uma média de 10 toneladas de madeira cada uma, depois de cortadas. Todas as espécies são abundantes, constituindo grandes viveiros, de todas as idades; de maneira que o suprimento não se esgotará tão cedo, com o desenvolvimento das árvores pequenas (DELANEY; LLOYD, 1913).

Isto posto, fica evidente a propaganda em torno das riquezas naturais brasileiras e a sua contribuição para a propagação de uma ideia de inesgotabilidade. Embora, uma maior necessidade de lenha e de madeira para o mercado interno e da venda de madeiras para melhorar a balança comercial, as análises negativas em torno dos desperdícios das matas começariam progressivamente a aumentar. Naturalmente, isso não significaria uma inversão da relação até então estabelecida como a natureza. Demais, se os discursos em defesa da agricultura científica se desenvolveram diante de alterações em pequena escala, o caso da silvicultura não seria tão distinto. Assim é que o artigo do engenheiro João Teixeira Soares ${ }^{21}$ na Revista A Lavoura, em 1918, apontava o desperdício de madeiras pela destruição de florestas devido à necessidade de posseiros justificarem a ocupação da maior área possível, além da constante expansão da agricultura por terras virgens gerada por uma técnica rudimentar. Segundo os seus cálculos, $80 \%$ dos destroços dessas florestas não eram utilizados, mas consumido no próprio local pelo fogo (Revista a Lavoura, 1918, p. 73).

Soares chama ainda a atenção para a necessidade de reformulação da gestão das companhias de estradas de ferro. Segundo a legislação referente à concessão de funcionamento das ferrovias vigente durante a Primeira República (BRASIL, 1889-1930), elas eram obrigadas a plantar as suas lavouras de árvores. Ele recomendava a criação de um grupo de reflorestadores, que possuíssem contratos de compra para a madeira e para a lenha que viessem a produzir. Além disso, essas companhias deveriam ser menos exigentes quanto às condições de qualidade e dimensões, de modo a tornar possível o mais completo aproveitamento das árvores abatidas (Revista a Lavoura, 1918, p. 73).

As ideias em torno da preocupação com o desmatamento no Brasil nasceram, assim, umbilicalmente, ligada à expansão do consumo de madeira. Seria, por outro lado, fundamental avaliar o discurso desses homens, até porque se tratava de um conjunto de assuntos que por vezes são analisados como estanques. Temas como atraso, progresso, agricultura, silvicultura, intervenção estatal dentre outros, emergiam ao mesmo tempo e eram frequentemente conciliados. Demais, no Brasil, não seria ainda possível por maiores que fossem o entendimento desses

21 João Teixeira Soares projetou o traçado ferrovia entre Itacaré e Santa Maria, no Rio Grande do Sul. 
acadêmicos em relação aos problemas causados pelo desmatamento que se implantasse uma postura fortemente preservacionista. Uma vez que maiores dificuldades esses homens encontrariam se defendessem um projeto pura e simplesmente de proteção da natureza, posto que nesse caso não fosse de esperar compreensão ou benevolência por parte dos grandes agricultores e, mesmo, do Estado. Até porque se vê, facilmente, a estreita relação de um mercado em crescimento e uma maior intervenção estatal. Em 1911, o Congresso Federal decretou um prêmio ao maior exportador de madeira de lei. Como se percebe pelo gráfico 1, durante a Primeira República, progressivamente, a exportação de madeiras iria aumentar a sua importância.

\section{Gráfico 1 - Exportação de madeiras do Brasil 1910- 1923}

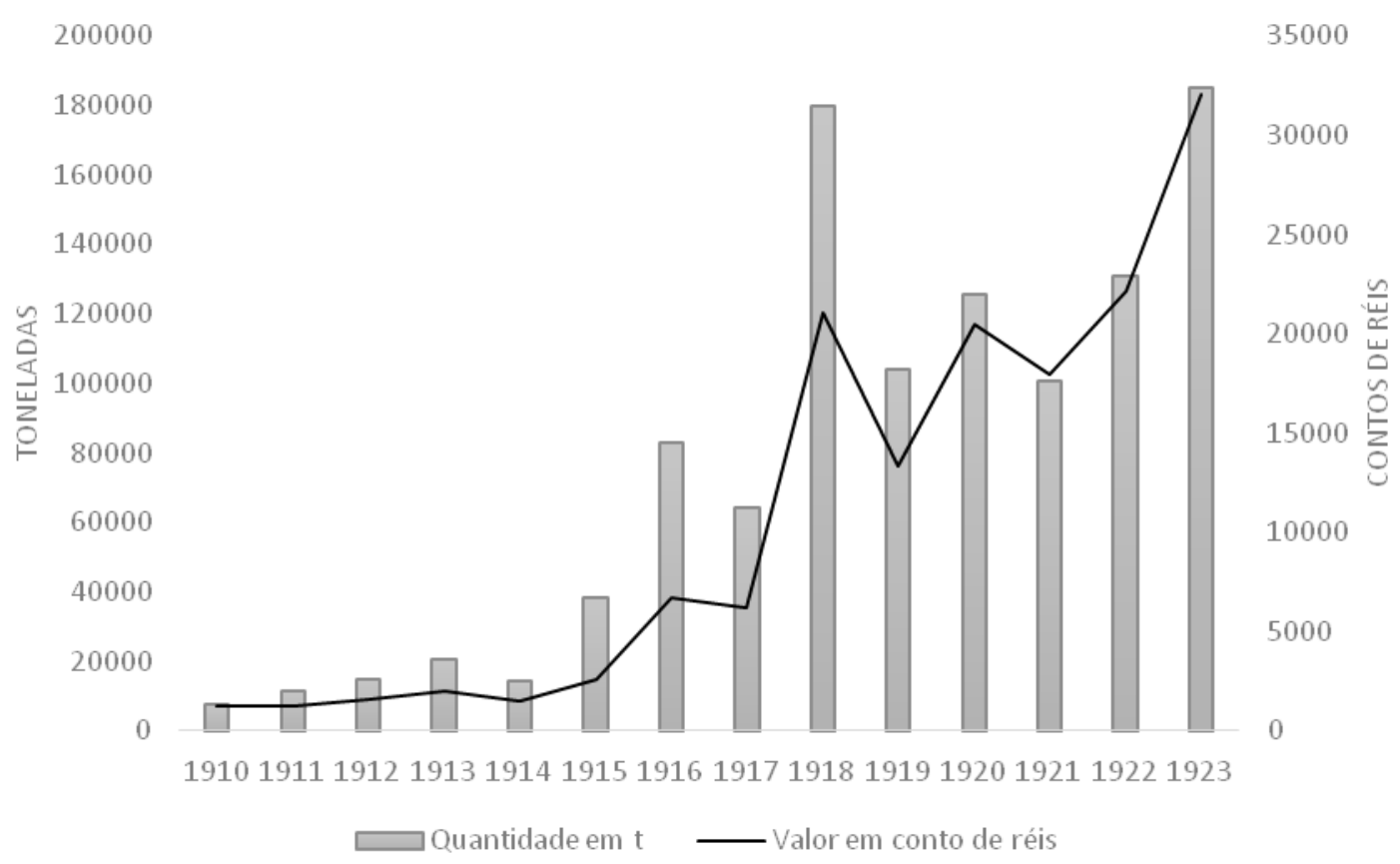

Fonte: Brasil (1925b, p. 96).

Aliás, a agricultura e a silvicultura, seriam ambas colocadas sobre a égide do MAIC. É preciso não esquecer que o projeto de criação do Ministério da Agricultura seria pensado e defendido pela Sociedade Nacional da Agricultura. Parece-nos curial que a sociedade teria predominante em seus quadros agricultores e técnicos (MENDONÇA, 1990), mas, principalmente, homens que estavam buscando abrir caminhos para um projeto que se contrapunha à monocultura cafeeira. Ou melhor, a necessidade de diversificação da produção seria constantemente apontada.

A chamada luta contra o "atraso" e a introdução de técnicas científicas seria a verdade menina dos olhos da Sociedade. Dessa maneira, o Ministério foi pensado como um conjunto de oficinas de trabalho científico. Sendo que a sua função seria a valorização desse conhecimento com vista a 
utilizar, dirigir e multiplicar os recursos naturais do Brasil, mas se valendo da "supremacia da ciência hodierna, ao invés do empirismo que nos faz ser por eles dirigidos e, não raro, vitimados" (SOCIEDADE NACIONAL DE AGRICULTURA, 1906, p. 70-79). Para isso, seria necessário preparar especialistas nacionais, instituições de ensino, fazendas modelos, hortos botânicos, etc. Acrescenta-se a tudo isso a defesa tão cara a esses homens ligados à Sociedade e depois ao Ministério da vocação agrícola do país. Como seria dito de forma laudatória, a agricultura e as riquezas naturais, eram o cerne da árvore do progresso nacional e não deveriam ser tratados como assunto de ordem secundária.

Quanto à questão específica das florestas, o recém-criado Ministério da Agricultura ficaria responsável pela conservação e reconstituição das florestas e matas, compreendendo também a da indústria extrativa. Ademais, teria o controle dos jardins botânicos, hortos, museus, laboratórios e faria a distribuição de mudas e sementes. A evolução dessas atividades não foi linear. Mas, houve efetivamente um esforço na distribuição de mudas e sementes. Além da publicação de vários folhetos que buscavam incentivar a silvicultura (SOCIEDADE NACIUONAL DE AGRICULTURA, 1906, p. 70-79). De qualquer forma, o papel do Ministério da Agricultura nessa questão iria tomando progressivamente um maior vulto. Era preciso incentivar a exportação de madeiras e a sua percepção como um valioso produto. Ao mesmo tempo, era preciso dar conta do consumo interno de lenha, minimizar os já perceptíveis males de um desmatamento descontrolado e atender as demandas dos agricultores.

Vê-se, assim, a estreita formação entre um mercado crescente de madeiras e, em contrapartida, as questões ambientais que, em maior ou menor proporção, contribuíram para estimular a defesa da criação do Serviço Florestal. Os seus principais objetivos seriam: "a conservação, reconstituição, formação e aproveitamento das florestas" (BRASIL, 1921). À vista disso, a ideia de vocação das riquezas naturais brasileiras, especialmente quando se falava no patrimônio florestal, não seria de todo modificava. De fato, o grande diferencial estava no aproveitamento racional das madeiras. Não obstante, a conservação das florestas figurar como uma das metas, não the seria dado o papel principal, embora contasse com a atuação de proeminentes acadêmicos em sua defesa. (FRANCO; DRUMMOND, 2009).

Quando enfim o decreto foi regulamentado em dezembro de 1925, a silvicultura já se firmara como a menina dos olhos de ouro desse projeto. Logo, no artigo primeiro, destacava-se que se deveria "sistematizar e propagar os conhecimentos relativos à silvicultura, mediante demonstrações práticas em hortos florestais, convenientemente situados, e em outras secções técnicas compreendidas no presente regulamento" (BRASIL, 1925a). Embora o ideal em torno da silvicultura ${ }^{22}$ criado em 1858 e, rapidamente difundido no ensino agrícola europeu, já fosse adotada no Império (ARAÚJO, 2010), a Primeira República criaria de fato as bases para a sua

22 Silvicultura seria a ciência que se dedica ao estudo dos métodos naturais e artificiais de regenerar e melhorar os povoamentos florestais e que compreende o estudo botânico das espécies, além da identificação, caracterização e prescrição da utilização das madeiras. (HOUAISS, 2001). 
implementação efetiva durante o Governo Vargas. Ou seja, as políticas ambientais do pós-30 fazem parte de um processo de lenta construção.

É digno de nota o fato de que na regulamentação do Serviço Florestal do Brasil os princípios da silvicultura seriam ressaltados em quase todos os parágrafos do decreto, tais como: exploração racional das florestas, criação de hortos florestais, melhor aproveitamento dos produtos das matas e a cultura das essenciais florestais que fornecessem matérias-primas às indústrias, experimentos referentes à mecânica da madeira, métodos de conservação, tratamento e utilização - levando em consideração às exigências dos mercados e da sua aplicação industrial -, organização de uma estatística florestal, a divulgação em publicações das ideias sobre os aspectos econômicos das florestas, a adoção da silvicultura comparada entre espécies locais e de outras zonas do país, a instrução elementar de silvicultura para os particulares, a criação de escolas teórico-práticas de silvicultura, florestas-modelo, silvo-pecuária, a contratação de engenheiros silvicultores, dentre outros (BRASIL, 1925b).

Não se restringiu ao Brasil a necessidade de intervenção nas áreas privadas por parte do Estado, mesmo que em princípios tenham sido feitas de forma mais esparsas. Como afirma Reinaldo Funes Monzote (2004, p. 398-399), a partir da década de 1920, o Governo cubano reveria a política de liberdade para o corte dos bosques, colocando limitações mesmo no caso das propriedades privadas. $\mathrm{O}$ desmatamento sem limites criou uma opinião favorável à defesa dos bosques e ao reflorestamento, tanto pela questão da salubridade do país como para evitar os contínuos gastos com madeiras compradas no estrangeiro que a llha de Cuba era capaz de produzir. Monzote resgata a fala do engenheiro José Isaac del Corral, que foi diretor das Florestas e das Minas da Secretaria de Agricultura, Comercio y Trabajo. Sendo responsável, na década de 1920, de implementar uma legislação que buscava regular a exploração das florestas e proteger espécies vegetais nativas. A preocupação em regularizar o corte das florestas em terras particulares era incisiva, como se pode perceber em um artigo publicado em 1923, nas páginas do Cuba Contemporánea:

Em cambio, gran parte de bosques de propiedad particular o de terrenos de igual categoria apropriados a la silvicultura, son de todo punto indispensables para el mantenimiento del área forestal del país, de donde resulta necessário someter dichos bosques o terrenos montuosos a um regimen forestal adecuado, que garantisse la conservación del arbolado, así como su restauración. José Isaac del Corral, " El problema forestal em Cuba” (apud MONZOTE, 2004, p. 108). 
Anos depois, José Alberto de Sampaio publicaria também um artigo intitulado "O problema florestal no Brasil em 1926" no Arquivo do Museu Nacional. E é nesse conjunto de ideias que circulavam que a fala de Sampaio se apoia. Ao citar a fala da Society of American Foresters23, segundo a qual a América do Sul destinava-se a ser o "centro da indústria mundial de madeiras" já simbolizava que este era um tema que, para ele, não poderia ser ignorado. (SAMPAIO, 1926). Realmente, era uma questão cara para esses homens a ideia de que a racionalização do comércio de madeiras era uma condição indispensável à continuidade das florestas. Isto posto, entende-se a importância dada por ele a atuação do recém-criado Serviço Florestal.

\footnotetext{
Esse equilíbrio entre os dois objetivos, produção intensa e eficiente conservação da flora nativa, depende naturalmente das conveniências econômicas que marcarão inflexivelmente a amplitude de cada um; mas o simples fato de ser visado, vale por si mesmo como prova de segura orientação no desenvolvimento da silvicultura racional no Brasil; será segura garantia de que o desenvolvimento da indústria extrativa de produtos florestais se fará, orientada pelo Serviço Florestal, de modo a se multiplicarem os plantios de florestas industriais, conservando-se em cada região uma reserva de matas nativas. (SAMPAIO, 1926).
}

Demais, uma questão de grande interesse surgiu nesse período: o Brasil poderia ocupar o posto de um dos maiores países produtores de madeiras, conservando ao mesmo tempo o máximo possível de suas florestas. Vê-se, assim, os motivos da silvicultura tornar-se um ponto crucial para esse conjunto às vezes disforme de atores e elementos que giravam em torno do Serviço Florestal. Assim, ao fazer a defesa da silvicultura, Sampaio deixava claro que o objetivo era a instauração de um regime de manejo florestal racional que propiciasse a conservação de reservas florestais.

\section{Considerações finais}

É oportuno notar que, neste afã por uma exploração racional das matas brasileiras, a criação de parques e reservas florestais que protegessem os sítios de beleza natural, a fauna e a flora indígenas começaram a figurar como a outra ponta da questão. No entanto, pode-se mesmo dizer que a criação do Serviço Florestal como uma secção especial do Ministério da Agricultura, Indústria

23 A Society of American Foresters foi fundada em 1900 buscava promover a exploração das florestas de maneira científica e racional 
e Comércio levaria o reconhecimento da natureza como um patrimônio a ser uma demanda menor. Embora já constassem das atribuições do Serviço Florestal na Primeira República, somente no Governo Vargas, as chamadas florestas protetoras e a criação dos parques nacionais receberiam uma maior atenção.

Por outro lado, a silvicultura ganhou movimentos próprios pelo seu entrelaçamento com a problemática da conservação do Patrimônio Natural. Ainda que, nesse momento, a floresta não fosse vista com o sentido hodierno, já se falava nos abusos nos cortes indiscriminados das matas e suas consequências negativas. Não se pode negar que a nascente República veria as matas brasileiras como um importante fornecedor de combustíveis, seja para as ferroviais, as recémcriadas usinas açucareiras, a indústria, dentre outros. Mas, os problemas causados pelo aumento do desmatamento fossem constantemente lembrados por agricultores, técnicos e acadêmicos brasileiros que tratavam das questões agrícolas, econômicas e ambientais nacionais.

A valorização comercial das madeiras brasileiras contaria com um número maior de defensores nesses anos. Assim como a silvicultura foi vista como uma saída para o crescente desflorestamento por aqueles que defendiam uma preservação de fato da natureza. Ledo engano das duas partes. Não obstante, fossem pensadas para caminhar de mãos dadas, a silvicultura não teria a força necessária para consolidar um modelo de exploração racional que evitasse a devastação das florestas brasileiras. Se o patrimônio florestal assumiu importância considerável no universo ideológico do Brasil na Primeira República, todavia na prática essas ideias não frutificaram como esperado. Ao propor uma transformação radical da visão florestal que vigorava na maior parte da sociedade brasileira desse período, esses homens tropeçavam em uma realidade onde não se sabia ainda que a floresta era patrimônio.

\section{Referências}

\section{Fonte Documental}

REVISTA A LAVOURA, Rio de Janeiro, dez. 1897.

REVISTA A LAVOURA, Rio de Janeiro, maio 1920.

REVISTA A LAVOURA, Rio de Janeiro, p. 73, jan./fev. 1918.

REVISTA DO MUSEU PAULISTA. São Paulo, 1911. 
REVISTA FLORESTAL DO BRASIL, [S. I.], n. 5, nov. 1902.

\section{Bibliografia}

ANDRADE, E. N. Utilidade das florestas. São Paulo: Tip. L. Alongi, 1912.

ARAÚJO, N. A. Pioneiros e hegemonia: a construção da agronomia como campo científico na Bahia (1832-1911). 2010. Tese (Doutorado em História) - PPGH/UFF, Nitéroi, 2010.

BARBOZA, C. H. História da meteorologia no Brasil (1887-1917). In: CONGRESSO BRASILEIRO DE METEOROLOGIA, 14., 2006, Florianópolis. Anais ... Rio de Janeiro: SBMET, 2006. v. 1. p. 1-6.

BHERING, M. J.; MAIO, M. C. Ciência, positivismo e agricultura: uma análise do Ministério da Agricultura, Indústria e Comércio na Primeira República. Varia Historia, Belo Horizonte, v. 27, n. 46, p. 689-709, jul./dez. 2011.

BRASIL. Coleção de leis da República dos Estados Unidos do Brasil. Rio de Janeiro: Imprensa Nacional, 1889-1930.

BRASIL. Decreto n‥ 17.042 de 16 de setembro de 1925. Coleção de Leis da República do Brasil de 1925. Rio de Janeiro: Tipografia Nacional, 1925a.

BRASIL. Decreto n․ 4.421 de 28 de dezembro de 1921. Coleção de Leis da República do Brasil de 1921. Rio de Janeiro: Tipografia Nacional, 1921.

BRASIL. Divisão de Geologia e Mineralogia. Boletim, 1926.

BRASIL. Ministério da Agricultura, Indústria e Comércio. Relatório apresentado ao presidente da República dos Estados Unidos do Brasil pelo Ministro da Agricultura Miguel Calmon du Pin e Almeida no ano de 1925. Rio de Janeiro: Imprensa Nacional, 1929.

BRASIL. Ministério da Agricultura, Indústria e Comércio. Tipografia do serviço de Estatística de setembro a outubro de 1912. Boletim, Rio de Janeiro, jun. 1925b.

BRASIL. Ministério da Agricultura. Florestas e silvicultura nos Estados Unidos: relatório preparado para a Comissão dos Estados Unidos de América para a exposição do Centenário do Brasil. Washington: Imprensa Nacional, 1922.

BRASIL. Relatório apresentado à Assembleia Geral Legislativa pelo Ministro e Secretário de Estado dos Negócios da Agricultura, Comércio e Obras Públicas, José Fernandes da Costa Pereira Júnior. Rio de Janeiro: Tipografia Americana, 1875. 
BRASIL. Relatório da repartição dos negócios da agricultura, comércio e obras públicas apresentado à Assembleia Geral Legislativa pelo respectivo Ministro e Secretário de Estado, Manoel Felizardo de Souza e Mello. Rio de Janeiro: Tip. Universal de Laemmert, 1861.

DE LUCA, T. R. A revista do Brasil: um diagnóstico para a (N)ação. São Paulo: Fundação Editora da Unesp, 1999.

DEAN, W. A ferro e a fogo: a história e a devastação da Mata Atlântica brasileira. São Paulo: Companhia das Letras, 1996.

DELANEY, L. T.; LLOYD, R. Impressões do Brasil no Século XX. Londres: Lloyds Greater Britain Publishing Company, 1913.

FIGUEIRÔA, S. F. M. 'Batedores da ciência' em território paulista: expedições de explorações e a ocupação do 'sertão' de São Paulo na transição para o século XX. História, Ciências e Saúde: Manguinhos, Rio de Janeiro, v. 15, n. 3, p. 763-777, jul./set. 2008.

FRANCO, J. L. A.; DRUMMOND, J. A. Proteção à natureza e identidade nacional no Brasil anos 1920-1940. Rio de Janeiro: Editora da Fiocruz, 2009.

GUYOT, C. L'enseignememt forestier em France: l'École de Nancy. Nancy: Crépin-Leblond, 1898.

HAMBURGER, A. I. et al. (Org). A ciência nas relações Brasil-França (1850-1950). São Paulo: Edusp, 1996.

HOBSBAWN, E. Da revolução industrial inglesa ao imperialismo. Rio de Janeiro: Forense, 1986.

HOUAISS. Dicionário eletrônico da língua portuguesa. Rio de Janeiro: Objetiva, 2001.

LEFF, E. Ecologia, capital e cultura: a territorialização da racionalidade ambiental. Petrópolis: Vozes, 2009.

MARTINI, A. J. O plantador de eucaliptos: a questão da preservação florestal no Brasil e o resgate documental do legado de Edmundo Navarro de Andrade. 2004. Dissertação (Mestrado) - USP, São Paulo, 2004.

MENDONÇA, S. R. Ruralismo: agricultura, poder e estado na primeira república. 1990. Tese (Doutorado) - FFLCH/USP, São Paulo, 1990.

MINAS GERAIS. Secretária de Agricultura. Serviço de Estatística. Cartograma da produção, extrativa, agrícola e pecuária. Minas Gerais, 1929.

MONZOTE, R. F. Tierras cansadas y quemadores de bagazo verde. La interacción com el médio natural y los câmbios em la industria azucarera cubana desde mediados del XIX. In: PIQUERAS, J. 
A. (Org.). Azúcar y esclavitud em el final del trabajo forzado. México D. F.:Fondo de Cultura Económica, 2002.

MONZOTE, R. F. De bosque a sabana. azúcar, deforestación y medioambiente en Cuba, 1492-1926. México: Siglo XXI Editores, 2004.

PÁDUA, J. A. Natureza e projeto nacional: as origens da ecologia política no Brasil. In: PÁDUA, J. A. (Org.). Ecologia e política no Brasil. Rio de Janeiro: Espaço e Tempo, 1987.

PICARD, J. Usinas açucareiras de Piracicaba, Villa-Haffard, Porto Feliz, Lorena e Cupim: missão de inspeção do Senhor J. Picard, Engenheiro, de 1 de março a 15 de julho de 1903. São Paulo: Hucitec, 1996.

SAMPAIO, A. J. O problema florestal no Brasil em 1926. Relatório sucinto visando a Phypotechnia e a Phytogeographia, abr./maio 1926.

SCHAMA, S. Paisagem e memória. São Paulo: Companhia das Letras, 1996.

SEVCENKO, N. Literatura como missão: tensões sociais e criação cultural na Primeira República. São Paulo: Companhia das Letras, 2003.

SOCIEDAde nACIONAL DE AGRICULTURA - SNA. Primeiro Congresso Nacional da Agricultura. Rio de Janeiro: Imprensa Nacional, 1907. v. 1 e 2.

SOCIEDADE NACIONAL DE AGRICULTURA - SNA. Projeto e parecer sobre a criação do Ministério da Agricultura, Indústria e comércio apresentado ao congresso nacional pelo deputado Dr. Joaquim Ignácio Tosta. Rio de janeiro: Imprensa Nacional, 1906.

STEIN, S. J. Grandeza e decadência do café no Vale do Paraíba. São Paulo: Brasiliense, 1981.

THOMAS, K. O homem e o mundo natural. São Paulo: Companhia de Letras, 1996.

WELCH, C. Policultura. In: MOTTA, M. (Org.). Dicionário da terra. Rio de Janeiro: Civilização Brasileira, 2005. p. 355-357.

WHITE, R. Você é um ambientalista ou trabalha para se sustentar: trabalho e natureza. Topoi, Rio de Janeiro, v. 14, n. 27, p. 472-491, jul./dez. 2013.

WILLIAMS, R. Culture \& society: 1780-1950. New York: University Press, 1983.

WORSTER, D. ¿Por qué necesitamos de la historia ambiental?. Revista Tareas, Panamá, n. 117, p. 119-131, may/ago. 2004.

Recebido em 02.08.2015 - aprovado em 07.12.2015 